\title{
Determinants of Knowledge, Attitude, and Practice Towards First Aid Among Kindergarten and Elementary School Teachers in Gondar City, Northwest Ethiopia
}

\section{Belayneh Shetie Workneh}

University Of Gondar

Enyew Getaneh Mekonen ( $\nabla$ enyewgetaneh12@gmail.com )

University Of Gondar

Mohammed Seid Ali

University Of Gondar

\section{Research Article}

Keywords: Attitude, first aid, knowledge, practice, teachers, Gondar city

Posted Date: February 26th, 2021

DOI: https://doi.org/10.21203/rs.3.rs-244642/v1

License: (c) (1) This work is licensed under a Creative Commons Attribution 4.0 International License.

Read Full License 


\section{Abstract}

Background: Injuries continue to be an important cause of morbidity and mortality in the developed and developing world. School-age children are more likely to experience unintentional injuries in the school, while they are playing and teachers are the primarily responsible body for keeping the welfare of the students. Knowing the knowledge, attitude, and practice of kindergarten and elementary school teachers towards first aid will be used as an input for policymakers to intervene and provide training. Therefore, this study was aimed to assess knowledge, attitude, practice, and associated factors towards first aid among kindergarten and elementary school teachers in Gondar city, Northwest Ethiopia, 2021.

Methods: An institution-based cross-sectional study was conducted from January 01 to 20, 2021. A simple random sampling technique was employed to recruit 346 participants. A structured pretested selfadministered questionnaire was used to collect data. Data were entered in Epi-info version 7, analyzed using SPSS version 21, and presented by frequencies, percentages, tables, and graphs. Bivariable relationships between the independent and outcome variable were investigated using a binary logistic regression model and a multivariable analysis was run to control potential confounding factors. Variables with a p-value $<0.05$ were considered as factors significantly associated and the strength of association was determined using an odds ratio with a $95 \% \mathrm{Cl}$.

Results: Only $41.1 \%$ of the teachers had good knowledge of first aid. Nearly two-thirds $(64.8 \%)$ of the teachers had a favorable attitude towards first aid. The majority (85.8\%) of the teachers who faced a child in need of first aid in their school gave first aid. Factors like working experience [AOR: $2.45 ; 95 \% \mathrm{Cl}$ $(1.26,4.73)]$, school level [AOR: 4.72; $95 \% \mathrm{Cl}(1.96,11.4)$ ], school type [AOR: $4.23 ; 95 \% \mathrm{Cl}(2.07,8.64)$ ], and having information about first aid [AOR: $2.09 ; 95 \% \mathrm{Cl}(1.11,3.92)]$ were significantly associated with knowledge. School-level [AOR $=5.4,95 \% \mathrm{Cl}(2.18-11.67)]$, school type [AOR $=0.45,95 \% \mathrm{Cl}(0.21-0.94)]$, and working experience $[\mathrm{AOR}=0.33,95 \% \mathrm{Cl}(0.13-0.86)]$ were the factors significantly associated with attitude.

Conclusion: Less than half and nearly two-thirds of the teachers had good knowledge and a favorable attitude towards first aid. The majority of the teachers who encountered a child in need of first aid gave first aid. Having higher working experience, working in elementary and private schools, and having previous information increases the odds of having good knowledge. Teachers who work in elementary and private schools and have lower working experience had higher odds of favorable attitude towards first aid. It is better to give attention to the training of staff on first aid specifically for teachers working in kindergarten and governmental schools and new employees and consider integrating first aid in teachers' training curriculum.

\section{Background}

First aid can be defined as the immediate care given to a person who has been injured or suddenly ill with materials available on hand to preserve life, alleviate suffering, prevent further illness or injury, and 
promote recovery $(1-3)$. It is one of the most important procedures to follow in case of a medical emergency or an accident. At least $39 \%$ of pre-hospital deaths are potentially preventable with better interventions (4). An accident is something harmful and takes place suddenly and unexpectedly that may result in simple injuries or major complications like broken bones with heavy bleeding, failure to breathe, unconsciousness, or even death (5). Many dangerous situations like fainting, falls, intoxications and road crashes that happen at home, school, or in the work-place affect victims and their relatives both physically and psychologically (3).

Unintentional injuries are the leading cause of morbidity and mortality for children (6). Injuries continue to be an important cause of morbidity and mortality in the developed and developing world (7). Globally more than 2000 families lost their child due to unintentional injury or accidents every day (5). The most common causes of accidents and injuries in school children are bullying and assaults, slip and fall accidents, school bus, and playground accidents, food poisoning, and sports activities which result in a significant number of serious injuries (8). Negligence in injuries or accidents at elementary and kindergarten schools causes the life-threatening condition (9). The majority of injuries are occurred during free play and on the playground and are precipitated by child-related factors, like being pushed. Boys had significantly higher median injury rates than girls (10).

In Ethiopia, the annual mortality caused by injuries is projected to increase from 10,697 in 2015 to 11,989 by 2030 among children less than 5 years and the number of deaths among 0-14-year olds will be 30,364 (11). School-age children are more likely to experience unintentional injuries in school, while they are playing. School teachers are the primarily responsible body for keeping the welfare of the students and oversee their activities. They are the first contact and responsible person when children faced injuries. However, studies showed that the level of knowledge and basic practice of first aid among school teachers were found to be poor (12-14).

A study conducted at Lideta sub-city, Addis Ababa and Jimma, Ethiopia among kindergarten teachers, showed that $79.9 \%$ and $50.4 \%$ of the teachers encountered a child in need of first aid, and $89.7 \%$ and $52.1 \%$ of teachers gave first aid respectively $(13,14)$. In the country, schools have not Emergency Medical Technician (EMT), paramedics, or other trained health professionals who will give first aid. However, prehospital school-based Emergency Medical Service (EMS) at school by school personnel is mandatory for saving the children from disability and death. Therefore, assessing the level of knowledge, attitude, and practice of kindergarten and elementary school teachers on first aid is important to intervene and provide training.

\section{Methods And Materials}

\section{Study design and period}

An institution-based cross-sectional study was conducted from January 01 to $20,2021$.

\section{Study setting}


The study was conducted at kindergarten and elementary schools found in Gondar city, Northwest Ethiopia. Gondar city is $727 \mathrm{Km}$ far from Addis Ababa, the capital city of Ethiopia, and $180 \mathrm{~km}$ from Bahir Dar, the capital city of Amhara regional state. Gondar city has a total area of $192.3 \mathrm{sq}$. KM. The city has a total population of 338, 646 peoples with 256,041 people whose age is between 18 and 65 years old in 6 sub-cities and 27 Kebele with a total of 78,772 households. Under the Gondar city administration education office there are 11 secondary, 64 elementary, and 70 kindergarten schools with a total of 2649 teachers.

\section{Study participants}

All kindergarten and elementary school teachers working in Gondar city who were available during the data collection period were included in the study. Those teachers who are seriously ill and attending external training courses off-site during the study period were excluded from the study.

\section{Sample size determination}

The sample size was calculated using the single population proportion formula by taking the estimated proportion of knowledge, attitude, and practice among kindergarten and elementary school teachers: $44 \%$ (13), a confidence level of $95 \%$, and a margin of error of $5 \%$. The final sample size was 346 after using a correction formula and adding a $10 \%$ non-response rate.

\section{Sampling technique and procedure}

A simple random sampling technique was employed to recruit the required participants for the study. First, we stratified participants into elementary and kindergarten school teachers, and then we allocated the required sample for each stratum proportionally. Finally, study participants were selected from each stratum by simple random sampling.

\section{Data collection instruments and procedures}

Data were collected using a structured pre-tested self-administered questionnaire. The questionnaire contains 43 questions arranged into four sections; the first section contains eight questions regarding the socio-demographic characteristics of the participants, the second section contains eleven questions regarding first aid knowledge of kindergarten and elementary school teachers, the third section contains seven attitude related questions, and the last section contains seventeen practice-related questions. The questionnaire was adapted from a similar study done at Addis Ababa, Ethiopia (14). Data were collected with the help of four trained BSc nurse data collectors and two MSc nurse supervisors. A written guideline was given to the data collectors to assure that every participant received the same directions and information. The anonymity of the participant was kept by informing them not to write their name. The instruments were distributed among the study population, after guarantying their willingness to take part in the study, and then it was collected by the data collectors after completion. During data collection data collectors and supervisors followed the recommended precautions to prevent COVID-19. 


\section{Data processing and analysis}

Data clean-up and cross-checking were done before analysis. Checked, cleaned, and coded data were entered into EPI info version 7 and exported to SPSS version 21 for analysis. Descriptive statistics like frequencies, percentages, mean and standard deviation, tables, and figures were used to present data. Bivariable relationships between each independent variable and outcome variable were investigated using a binary logistic regression model. Those independent variables with a p-value $<0.2$ at the bivariable level were included in multivariable analysis to control potential confounding factors. After adjusting their effect on the outcome variable, those variables with a p-value $<0.05$ with a $95 \%$ confidence interval were regarded as factors significantly associated.

\section{Data quality assurance}

The data collection tool was pretested before the actual data collection time at Bahir Dar city kindergarten and elementary schools, which were not included in the study using $5 \%$ of the total sample size. Amendments on the instrument, such as unclear questions and ambiguous words were made accordingly. The pretest was also used to estimate how much time it takes to administer the entire questionnaire. The tool was first developed in the English language and translated to the Amharic language with back translation to English for consistency. The one-day training was given to data collectors and supervisors on the objective of the study, instrument, and data collection procedures by the principal investigators. Supervision was conducted by the principal investigators and supervisors. To ensure data quality, each data collector checked the questionnaire from each study participant for completeness daily. The supervisors and principal investigators reviewed each questionnaire daily and checked for completeness.

\section{Results}

\section{Socio-demographic characteristics of the respondents}

A total of 338 respondents have participated in the study with a $97.7 \%$ response rate. Among the total participants, two hundred twelve (62.7\%) respondents were females. One-third (33.4\%) of the respondents were in the age group of above 42 years. Of the total participants, two hundred nineteen $(64.8 \%)$ respondents were degree holders. Two hundred thirteen (67.5\%) of the respondents were married. Among the total respondents, one hundred three $(30.5 \%)$ respondents had greater than ten years of work experience in teaching. Majorities (84.9\%) of the respondents were from primary schools and the rest were from kindergarten schools and two hundred sixty-six (77.8\%) of the respondents were from government schools. Most (71.6\%) of the respondents did not take the training in first aid (Table 1). 
Table 1

Socio-demographic characteristics of kindergarten and elementary school teachers in Gondar city, Northwest Ethiopia, 2021 ( $n=338$ )

\begin{tabular}{|c|c|c|c|}
\hline Variables & Response & Frequency & Percentage (\%) \\
\hline \multirow[t]{2}{*}{ Sex } & Male & 126 & 37.3 \\
\hline & Female & 212 & 62.7 \\
\hline \multirow[t]{3}{*}{ Age } & 22-31years & 108 & 32.0 \\
\hline & $32-41$ years & 117 & 34.6 \\
\hline & Above 42 years & 113 & 33.4 \\
\hline \multirow[t]{3}{*}{ Level of education } & Certificate & 9 & 2.7 \\
\hline & Diploma & 110 & 32.5 \\
\hline & Degree & 219 & 64.8 \\
\hline \multirow[t]{4}{*}{ Marital status } & Married & 213 & 67.5 \\
\hline & Single & 101 & 29.9 \\
\hline & Divorced & 15 & 4.4 \\
\hline & Widowed & 9 & 2.7 \\
\hline \multirow[t]{3}{*}{ Service year } & $\leq 10$ years & 146 & 43.2 \\
\hline & $11-20$ years & 89 & 26.3 \\
\hline & $\geq 21$ years & 103 & 30.5 \\
\hline \multirow[t]{2}{*}{ School-level } & Kindergarten & 51 & 15.1 \\
\hline & Elementary & 287 & 84.9 \\
\hline \multirow[t]{2}{*}{ School type } & Government & 263 & 77.8 \\
\hline & Private & 75 & 22.2 \\
\hline \multirow[t]{2}{*}{ Do you have training on first aid } & Yes & 96 & 28.4 \\
\hline & No & 242 & 71.6 \\
\hline
\end{tabular}

\section{Knowledge of kindergarten and elementary school teachers towards first aid}

Of the total respondents, only $41.1 \%$ (with $95 \% \mathrm{Cl}(35.9 \%, 45.7 \%)$ ) of the respondents had good knowledge of first aid (Figure 1). The majority (81.7\%) of the participants had information about first aid. Of these, $10.9 \%, 7.6 \%, 21.0 \%$, and $60.5 \%$ were heard from family, books, media, and health professionals respectively. The majority (93.5\%) of the respondents correctly respond to what first aid means. Nearly 
two-thirds (66.3\%) of the participants were aware of giving nothing by mouth for fainting children. More than three fourth $(79.6 \%)$ of the respondents understand the concept of immobilization for neck and back injuries (Table 2).

Table 2

Knowledge of kindergarten and elementary schools teachers towards first aid in Gondar city, Northwest Ethiopia, $2021(n=338)$

\begin{tabular}{|c|c|c|}
\hline \multirow[t]{2}{*}{ Item } & \multicolumn{2}{|c|}{ Responses } \\
\hline & Yes (\%) & No (\%) \\
\hline Have you ever heard about first aid & $\begin{array}{l}276 \\
(81.7)\end{array}$ & $62(18.3)$ \\
\hline $\begin{array}{l}\text { First aid is the immediate care given for a person who sustained an injury } \\
\text { or accident before the victim arrives health institution }\end{array}$ & $316(93.5)$ & $22(6.5)$ \\
\hline $\begin{array}{l}\text { Pressing firmly with a clean bandage the bleeding part is one of the } \\
\text { measures to stop bleeding }\end{array}$ & $301(89.1)$ & $37(10.9)$ \\
\hline Giving fluid by mouth is one of the first aid measures for fainting a child & 114(33.7) & 224(66.3) \\
\hline $\begin{array}{l}\text { One of the first aid measures for an epileptic child is keeping the airway } \\
\text { clear by placing the child on his/her back }\end{array}$ & $229(67.8)$ & 109(32.2) \\
\hline $\begin{array}{l}\text { Standing behind the child encircling the child's chest by hands and } \\
\text { squeezing is the first aid measure for choking a child }\end{array}$ & $240(71.0)$ & $98(29.0)$ \\
\hline $\begin{array}{l}\text { For a child with neck and back injury avoiding head and neck movement } \\
\text { and keeping the body straight is one measure of first aid }\end{array}$ & 269(79.6) & $69(20.4)$ \\
\hline $\begin{array}{l}\text { In case a child has bitten by his friend, cleansing wound with soap and } \\
\text { water for } 5 \text { minutes is one measure of first aid for a human bite }\end{array}$ & 233(68.9) & 105(31.1) \\
\hline $\begin{array}{l}\text { One of the first aid measures for nose bleed/epistaxis is placing student } \\
\text { sitting comfortably with slightly backward and applying uninterrupted } \\
\text { pressure by pressing nostrils together }\end{array}$ & $257(76.0)$ & $81(24.0)$ \\
\hline $\begin{array}{l}\text { Encouraging the child to sit quietly, breathe slowly and deeply in through } \\
\text { the nose and out through the mouth is the first aid measure for the child } \\
\text { with the difficulty of breathing }\end{array}$ & 292(86.4) & $46(13.6)$ \\
\hline
\end{tabular}

\section{The attitude of kindergarten and elementary school teachers towards first aid}

Among the total participants, nearly two-thirds $(64.8 \%)$ with $95 \% \mathrm{Cl}(59.2 \%-69.8 \%)$ of the respondents had a favorable attitude towards first aid (Figure 1). About two hundred (59.2\%) of the respondents strongly agreed with the idea giving first aid at school is fair. One hundred three $(30.5 \%)$ of the respondents were strongly disagreed with giving first aid at school is unpleasant. About half $(49.4 \%)$ of the respondents were strongly disagreed with giving first aid is not good. About two hundred seven (61.2\%) of the respondents were strongly agreed with giving special care for injured children in academic work is appropriate (Table 3 ). 
Table 3

Attitude of kindergarten and elementary school teachers towards first aid in Gondar city, Northwest Ethiopia, $2021(n=338)$

\begin{tabular}{|lllll|}
\hline Item & Response & & \\
\hline & $\begin{array}{l}\text { Strongly } \\
\text { disagree }\end{array}$ & Disagree & Agree & $\begin{array}{c}\text { Strongly } \\
\text { agree }\end{array}$ \\
\cline { 2 - 5 } & $\begin{array}{l}\text { Frequency } \\
(\%)\end{array}$ & $\begin{array}{l}\text { Frequency } \\
(\%)\end{array}$ & $\begin{array}{l}\text { Frequency } \\
(\%)\end{array}$ & $\begin{array}{l}\text { Frequency } \\
(\%)\end{array}$ \\
\hline Giving first aid at school is fair & $35(10.4)$ & $20(5.9)$ & $83(24.3)$ & $200(59.2)$ \\
\hline Giving first aid at school is unpleasant & $103(30.5)$ & $167(49.4)$ & $49(14.5)$ & $19(5.6)$ \\
\hline Giving first aid is not good & $167(49.4)$ & $129(38.2)$ & $28(8.3)$ & $14(4.1)$ \\
\hline It is good for me to provide first aid & $26(7.7)$ & $23(6.8)$ & $97(28.7)$ & $192(56.8)$ \\
\hline I need to learn first aid & $29(8.6)$ & $21(6.2)$ & $85(25.1)$ & $203(60.1)$ \\
\hline $\begin{array}{l}\text { It is the responsibility of the teacher to giving } \\
\text { first aid care for children in need }\end{array}$ & $26(7.7)$ & $62(18.3)$ & $169(50.0)$ & $81(24.0)$ \\
\hline $\begin{array}{l}\text { Giving special care for injured children in } \\
\text { academic work is appropriate }\end{array}$ & $23(6.8)$ & $22(6.5)$ & $86(25.4)$ & $207(61.2)$ \\
\hline
\end{tabular}

\section{The practice of kindergarten and elementary school teachers towards first aid}

More than three-fourths (76.9\%) of the teachers faced a child in need of first aid in their school and $85.8 \%$ of them gave first aid for the child. Ninety-five $(28.1 \%)$ of the participants faced a child with the difficulty of breathing and nearly half (49.5\%) of them encouraged the student to sit quietly. One hundred forty-six $(43.2 \%)$ of the respondents faced a child with fainting and $75.3 \%$ of them kept the student in a flat position. Nearly three-fourths $(74.9 \%)$ of the teachers faced a child with bleeding from his/her nose and more than half (51.0\%) of them applied uninterrupted pressure by pressing nostrils together. Nearly half (50.6\%) of the participants faced a child with bleeding on his/her body and $35.1 \%$ of them pressed firmly with a clean bandage to stop bleeding. One hundred forty-eight (43.8\%) of the teachers faced a child with seizure/epilepsy and $41.2 \%$ of them moved surrounding objects to avoid injury. Nearly one-third of the respondents faced a child with choking and more than half (58.3\%) of them stood behind the child encircling the child's chest by hands and squeezed. Nearly one-fifth (19.5\%) of the participants faced a child with an injured neck and back and more than half (54.6\%) of them avoided head and neck movement and kept their body straight (Table 4). 
Table 4

Practice of kindergarten and elementary school teachers towards first aid in Gondar city, Northwest Ethiopia, $2021(n=338)$

\begin{tabular}{|c|c|c|}
\hline Item & Response & $\begin{array}{l}\text { Frequency } \\
\text { (percentage) }\end{array}$ \\
\hline \multirow{2}{*}{$\begin{array}{l}\text { Have you ever faced a child in } \\
\text { need of first aid in your school? }\end{array}$} & Yes & $260(76.9 \%)$ \\
\hline & No & $78(23.1 \%)$ \\
\hline \multirow{2}{*}{$\begin{array}{l}\text { If yes, did you give first aid }(n= \\
260) ?\end{array}$} & Yes & $223(85.8 \%)$ \\
\hline & No & $37(14.2 \%)$ \\
\hline \multirow{2}{*}{$\begin{array}{l}\text { Have you ever faced a child with } \\
\text { the difficulty of breathing? }\end{array}$} & Yes & $95(28.1 \%)$ \\
\hline & No & $243(71.9 \%)$ \\
\hline \multirow[t]{3}{*}{ If yes, what did you do $(n=95) ?$} & Called ambulance & $33(34.7 \%)$ \\
\hline & Encouraged the student to sit quietly & $47(49.5 \%)$ \\
\hline & $\begin{array}{l}\text { Encouraged slow and deep breath in through the } \\
\text { nose and out through the mouth }\end{array}$ & $15(15.8 \%)$ \\
\hline \multirow{2}{*}{$\begin{array}{l}\text { Have you ever faced a child with } \\
\text { fainting? }\end{array}$} & Yes & $146(43.2 \%)$ \\
\hline & No & $192(56.8 \%)$ \\
\hline \multirow[t]{3}{*}{ If yes, what did you do $(n=146)$ ? } & Called ambulance & $15(10.3 \%)$ \\
\hline & Kept the student in a flat position & $110(75.3 \%)$ \\
\hline & Loosen clothing around the neck and waist & $21(14.4 \%)$ \\
\hline \multirow{2}{*}{$\begin{array}{l}\text { Have you ever faced a child with } \\
\text { bleeding from his/her nose? }\end{array}$} & Yes & $253(74.9 \%)$ \\
\hline & No & $85(25.1 \%)$ \\
\hline \multirow[t]{4}{*}{ If yes, what did you do $(n=253)$ ? } & Called ambulance & $21(8.3 \%)$ \\
\hline & Laid on the side with head raised on a pillow & $57(22.5 \%)$ \\
\hline & $\begin{array}{l}\text { Applied uninterrupted pressure by pressing } \\
\text { nostrils together }\end{array}$ & $129(51.0 \%)$ \\
\hline & Applied ice to nose & 46 (18.2\%) \\
\hline \multirow{2}{*}{$\begin{array}{l}\text { Have you ever faced a child with } \\
\text { bleeding on his/her body? }\end{array}$} & Yes & $171(50.6 \%)$ \\
\hline & No & 167 (49.4\%) \\
\hline
\end{tabular}




\begin{tabular}{|c|c|c|}
\hline Item & Response & $\begin{array}{l}\text { Frequency } \\
\text { (percentage) }\end{array}$ \\
\hline \multirow[t]{4}{*}{ If yes, what did you do $(n=171) ?$} & Called ambulance & $18(10.5 \%)$ \\
\hline & $\begin{array}{l}\text { Pressed firmly with a clean bandage to stop } \\
\text { bleeding }\end{array}$ & \multirow{3}{*}{$\begin{array}{l}60(35.1 \%) \\
50(29.2 \%) \\
43(25.2 \%)\end{array}$} \\
\hline & Flovatod hlooding hodv nart gontlv & \\
\hline & $\begin{array}{l}\text { Bandaged bleeding wound without interfering } \\
\text { circulation }\end{array}$ & \\
\hline \multirow{2}{*}{$\begin{array}{l}\text { Have you ever faced a child with } \\
\text { seizure/epilepsy? }\end{array}$} & Yes & $148(43.8 \%)$ \\
\hline & No & $190(56.2 \%)$ \\
\hline \multirow[t]{4}{*}{ If yes, what did you do $(n=148) ?$} & Called ambulance & $6(4.1 \%)$ \\
\hline & Placed on the floor & $53(35.8 \%)$ \\
\hline & Moved surrounding objects to avoid injury & $61(41.2 \%)$ \\
\hline & Avoided giving any drink or food by mouth & $28(18.9 \%)$ \\
\hline \multirow{2}{*}{$\begin{array}{l}\text { Have you ever faced a child with } \\
\text { choking? }\end{array}$} & Yes & $108(32.0 \%)$ \\
\hline & No & $230(68.0 \%)$ \\
\hline \multirow[t]{3}{*}{ If yes, what did you do $(n=108) ?$} & Called ambulance & $6(5.6 \%)$ \\
\hline & $\begin{array}{l}\text { Stood behind the child encircling the child's } \\
\text { chest by hands and squeezed }\end{array}$ & \multirow{2}{*}{$\begin{array}{l}63(58.3 \%) \\
39(36.1 \%)\end{array}$} \\
\hline & Continued squeezing until the object expelled & \\
\hline \multirow{2}{*}{$\begin{array}{l}\text { Have you ever faced a child with } \\
\text { an injured neck and back? }\end{array}$} & Yes & $66(19.5 \%)$ \\
\hline & No & $272(80.5 \%)$ \\
\hline \multirow[t]{3}{*}{ If yes, what did you do $(n=66) ?$} & Called ambulance & $9(13.6 \%)$ \\
\hline & $\begin{array}{l}\text { Laid the student and restrict moving unless harm } \\
\text { exacerbated if the students stayed there }\end{array}$ & $21(31.8 \%)$ \\
\hline & $\begin{array}{l}\text { Avoided head and neck movement and kept } \\
\text { body straight }\end{array}$ & $36(54.6 \%)$ \\
\hline
\end{tabular}

\section{Factors associated with knowledge of teachers towards first aid}

Using bivariable logistic regression analysis age, experience, school level, school type, training, having information about first aid, and history of exposure with a child in need of first aid were found to be significantly associated with knowledge. In multivariable logistic regression analysis, working experience, 
school level, school type, and having information about first aid were significantly associated with the knowledge of teachers towards first aid.

Teachers who worked for 11-20 years were nearly three times higher to be knowledgeable compared with teachers who worked for less than 10 years [AOR: $2.45 ; 95 \% \mathrm{Cl}(1.26,4.73)]$. Those teachers working at elementary schools were nearly five times higher to have good knowledge compared with teachers working at kindergarten schools [AOR: $4.72 ; 95 \% \mathrm{Cl}(1.96,11.4)$ ]. Those study participants who work at private schools were nearly four times higher to have good knowledge about first aid compared with governmental school teachers [AOR: $4.23 ; 95 \% \mathrm{Cl}(2.07,8.64)]$. Those teachers who had information about first aid were two times higher to have good knowledge compared with their counterparts [AOR: 2.09; 95\% Cl (1.11, 3.92)] (Table 5). 
Table 5

Bivariable and multivariable logistic regression analysis of factors associated with knowledge towards first aid among kindergarten and elementary school teachers in Gondar city, Northwest Ethiopia, 2021 (n = 338)

\begin{tabular}{|c|c|c|c|c|c|c|}
\hline \multirow[t]{2}{*}{ Variables } & & \multicolumn{2}{|c|}{ Knowledge } & \multicolumn{2}{|l|}{ OR with $95 \% \mathrm{Cl}$} & \multirow{2}{*}{$\begin{array}{l}\mathrm{P}- \\
\text { value }\end{array}$} \\
\hline & & Good & Poor & Crude & Adjusted & \\
\hline \multirow[t]{4}{*}{ Age } & $>=42$ & 58 & 55 & $2.30(1.33,3.97)$ & $2.20(0.64$ & 0.213 \\
\hline & $32-41$ & 47 & 70 & 1.46(0.84, & $125(062$ & 0.441 \\
\hline & $22-31$ & 34 & 74 & & 2.91) & \\
\hline & & & & 1 & 1 & \\
\hline \multirow[t]{4}{*}{ Experience } & $>=20$ & 48 & 55 & \multirow{2}{*}{$\begin{array}{l}1.90(1.13 \\
3.20)\end{array}$} & \multirow{2}{*}{$\begin{array}{l}\text { 1.81(0.96, } \\
3.43)\end{array}$} & 0.068 \\
\hline & $11-20$ & 45 & 44 & & & $0.008 *$ \\
\hline & $<=10$ & 46 & 100 & $3.83)$ & $\begin{array}{l}2.45(1.20, \\
4.73)\end{array}$ & \\
\hline & & & & 1 & 1 & \\
\hline \multirow[t]{2}{*}{ School-level } & \multirow{2}{*}{$\begin{array}{l}\text { Elementary } \\
\text { Kindergarten }\end{array}$} & 129 & 15841 & $\begin{array}{l}3.35(1.61, \\
6.94)\end{array}$ & $\begin{array}{l}4.72(1.96 \\
11.40)\end{array}$ & $0.001 *$ \\
\hline & & 10 & & 1 & 1 & \\
\hline \multirow[t]{3}{*}{ School type } & \multirow{3}{*}{$\begin{array}{l}\text { Private } \\
\text { Governmental }\end{array}$} & 40 & 35 & \multirow{2}{*}{$\begin{array}{l}1.89(1.13 \\
3.18)\end{array}$} & \multirow{2}{*}{$\begin{array}{l}4.23 \\
(2.07 \\
8.64)\end{array}$} & \multirow{3}{*}{ <. } \\
\hline & & 99 & 164 & & & \\
\hline & & & & 1 & 1 & \\
\hline \multirow[t]{3}{*}{ Training } & Yes & 51 & 45 & \multirow{2}{*}{$\begin{array}{l}1.98(1.23 \\
3.20)\end{array}$} & \multirow{2}{*}{$\begin{array}{l}1.28(0.75 \\
2.18)\end{array}$} & \multirow[t]{3}{*}{0.338} \\
\hline & \multirow[t]{2}{*}{ No } & \multirow[t]{2}{*}{88} & \multirow[t]{2}{*}{154} & & & \\
\hline & & & & 1 & 1 & \\
\hline Having previous & Yes & 121 & 155 & $\begin{array}{l}1.91(1.05 \\
347)\end{array}$ & 2.09 & $0.023^{*}$ \\
\hline \multirow[t]{2}{*}{ Information } & \multirow[t]{2}{*}{ No } & \multirow[t]{2}{*}{18} & \multirow[t]{2}{*}{44} & & 3.92) & \\
\hline & & & & r & 1 & \\
\hline \multirow{3}{*}{$\begin{array}{l}\text { Previous experience of } \\
\text { situations requiring } \\
\text { first aid }\end{array}$} & Yes & 120 & 140 & \multirow{2}{*}{$\begin{array}{l}2.66(1.50 \\
4.71)\end{array}$} & \multirow{2}{*}{$\begin{array}{l}\text { 1.80(0.97, } \\
3.34)\end{array}$} & \multirow[t]{3}{*}{0.065} \\
\hline & No & 19 & 59 & & & \\
\hline & & & & 1 & 1 & \\
\hline
\end{tabular}


Bivariable and multivariable logistic regression analyses were carried out. Age, training, school level, school type, and experience were eligible for multivariable analysis. In multivariable analysis, the factors significantly associated with the attitude of the participants were; school level, school type, and experience. Teachers who work in elementary schools were five times more likely to have a favorable attitude towards first aid than teachers who work in kindergarten [AOR $=5.4,95 \% \mathrm{Cl}(2.18-11.67)]$. Teachers who work in private schools were $55 \%$ times more likely to have a favorable attitude towards first aid than teachers who work in governmental schools [AOR $=0.45,95 \% \mathrm{Cl}(0.21-0.94)]$. Teachers who work for ten and below ten years were $67 \%$ times more likely to have a favorable attitude towards first aid than teachers who work for greater than equal to 21 years [AOR $=0.33,95 \% \mathrm{Cl}(0.13-0.86)$ ] (Table 6).

Table 6

Bivariable and multivariable logistic regression analysis of factors associated with the attitude of teachers towards first aid in Gondar city, Northwest Ethiopia, $2021(n=338)$

\begin{tabular}{|c|c|c|c|c|c|c|}
\hline \multirow[t]{2}{*}{ Variable } & \multirow[t]{2}{*}{ Response } & \multicolumn{2}{|c|}{ Attitude } & \multirow[t]{2}{*}{$\operatorname{COR}(95 \% \mathrm{Cl})$} & \multirow[t]{2}{*}{ AOR $(95 \% \mathrm{Cl})$} & \multirow[t]{2}{*}{ P-value } \\
\hline & & Good & Poor & & & \\
\hline \multirow[t]{3}{*}{ Age } & $22-31$ years & 67 & 41 & 1.0 & 1.0 & \\
\hline & $32-41$ years & 79 & 38 & $1.27(0.73-2.20)$ & $1.07(0.48-2.38)$ & 0.855 \\
\hline & $>42$ years & 73 & 40 & $1.11(0.64-1.93)$ & $0.39(0.11-1.33)$ & 0.133 \\
\hline \multirow[t]{2}{*}{ Training } & Yes & 91 & 68 & $0.68(0.41-1.14)$ & $0.81(0.47-1.41)$ & 0.467 \\
\hline & No & 151 & 28 & 1.0 & 1.0 & \\
\hline \multirow[t]{2}{*}{ School-level } & Kindergarten & 26 & 25 & 1.0 & 1.0 & \\
\hline & Elementary & 193 & 94 & $1.97(1.08-3.60)$ & $5.4(2.18-11.67)$ & $0.001^{*}$ \\
\hline \multirow[t]{2}{*}{ School type } & Government & 169 & 94 & $0.89(0.52-1.54)$ & $0.45(0.21-0.94)$ & $0.034^{*}$ \\
\hline & Private & 50 & 25 & 1.0 & 1.0 & \\
\hline \multirow[t]{3}{*}{ Experience } & $\leq 10$ years & 93 & 53 & 1.0 & 1.0 & \\
\hline & $11-20$ years & 56 & 33 & $0.96(0.56-1.67)$ & $0.37(0.16-1.23)$ & 0.106 \\
\hline & $\geq 21$ years & 70 & 33 & $1.2(0.71-2.06)$ & $0.33(0.13-0.86)$ & $0.024^{*}$ \\
\hline
\end{tabular}

\section{Discussion}

The result of this study revealed that only $41.1 \%$ of the respondents have good knowledge of first aid. The finding of this study is in line with previous studies conducted in Addis Ababa, 40.0\% (14), Debretabor, 45.8\% (12), and Jimma, Ethiopia 44.4\% (13). According to the participant's response, 85.8\% of the respondents report as they give first aid for injuries and illness however less than half of the 
participants have good knowledge. It implies that some of the teachers exercise first aid interventions without basic knowledge. It shall be given attention and first aid training to equip school teachers with first aid knowledge to give evidence-based first aid for accidents.

The finding of this study was higher than a study conducted in Saudi Khamis mushyt city, $19.6 \%$ (19). The difference might be due to variation in sample size and socio-demographic characteristics of the respondents. On the other hand, the result of this study was lower than the studies conducted in Malaysia $77.4 \%$ (15), Iraq 95\% (16), Indonesia 97\% (17), and Nigeria 66.5\% (17). The possible reason for this variation might be due to differences in a school setup, socio-demographic characteristics of the respondents, and variation in the measurement.

This study revealed that $64.8 \%$ of kindergarten and elementary school teachers had a favorable attitude towards first aid. This finding was in line with a study conducted in Saud Arabia (67\%) (22) and Riyadh $(68.4 \%)(23)$. This might be due to the similarities of teachers in academic activities in the school. However, this finding was lower than studies conducted in Debre tabor, Ethiopia (75\%) (12), Addis Ababa, Ethiopia (75\%) (14), and Jatinangor (71.5\%) (17). This discrepancy might be due to the variation of teacher's academic performance, knowledge, training about first aid, and the school settings across those areas.

In the current study, $85.8 \%$ of the teachers who encountered children in need of first aid gave first aid to the child. This finding is relatively consistent with a study conducted in Addis Ababa, Ethiopia (89.7\%) (14). However, it is higher than studies conducted in Debre Tabor, Ethiopia (64\%), Jimma, Ethiopia (52.1\%), Khamis Mushayt City, Saudi Arabia (54.9\%), and Indonesia (78.8\%) $(12,13,17,19)$. The possible justification for this difference might be due to the difference in data collection tool used in each study, study participants, and knowledge level. The current study was conducted among kindergarten and elementary school teachers whereas the previous studies were conducted among either kindergarten or elementary school teachers.

Working experience, school level, school type, and having information about first aid were significantly associated with knowledge towards first aid. The odds of having good knowledge were nearly three times higher among teachers who had 11-20 years of experience compared with those teachers who had less than ten years of experience. This finding was supported by studies conducted in Debre tabor, Ethiopia, Addis Ababa, Nigeria, Malaysia, Al-Qassim Saudi Arabia, and Khamis Mushyt city Saudi Arabia (12, 14, $15,18-20)$. This might be due to learning from experience in addition to facing individuals in need of first aid, training on first aid, and pre-hospital service. The finding of this study revealed that special consideration should be given to the newly employed teachers.

The odds of having good knowledge were three higher among elementary school teachers compared with kindergarten school teachers. It might be due to the difference in the level of education. According to the result of this study, almost all of the elementary school teachers were diploma and degree holders while kindergarten school teachers were certificate. This implies that special attention should be given to kindergarten school teachers since they give care for kids who didn't aware of their environment and 
susceptible to accidents. Private school teachers were four times higher to be knowledgeable compared with teachers who work at governmental schools. This might be due to the difference in a school setup. Most of the time private schools are business-oriented, competitive, and well equipped with infrastructures including first aid kits. Similarly, Participants who had previous information about first aid were two times higher to be knowledgeable compared with their counterparts. This finding is supported by studies conducted in Addis Ababa (17) and Debretabor, Ethiopia (12). This might be due to having previous information regarding first aid leads to a higher score of knowledge-related questions than respondents who didn't have information about the issue.

School-level, school type, and working experience were significantly associated with the attitude towards first aid. Teachers who work in elementary schools were five times more likely to have a favorable attitude towards first aid compared with teachers who work in kindergarten schools. This might be due to those teachers who work in primary schools were more knowledgeable about first aid since the school level determines the teacher's competency. Private school teachers were $55 \%$ more likely to have a favorable attitude towards first aid than teachers who work in governmental schools. This might be due to private schools might have good standards and structures of the school including first aid kits and their teachers also might have strict control since private schools are business-oriented. Similarly, the working experience was significantly associated with the attitude of teachers towards first aid. Teachers who had working experience of less than or equal to ten years were $67 \%$ more likely to have a favorable attitude compared with teachers who had working experience of greater than or equal to 21 . This finding was supported by other studies (14), (24), (25). This might be due to those teachers with long time experience give less attention to first aid because mostly they are old age and their academic status is diploma whereas younger age groups of teachers were degree holders.

This study has some limitations: There might be a possibility of social desirability and recall bias. We were unable to identify factors associated with practice due to the variation in the type of cases requiring first aid. The generalizability of the findings to schools in other parts of the country might be compromised since the study was conducted in one city. We were also unable to make an adequate comparison with other studies due to the lack of similar studies.

\section{Conclusion}

Less than half and nearly two-thirds of the teachers had good knowledge and a favorable attitude towards first aid. The majority of the teachers who encountered a child in need of first aid gave first aid. Having higher working experience, working in elementary and private schools, and having previous information about first aid increases the odds of having good knowledge of first aid. Teachers who work in elementary and private schools and have lower working experience had higher odds of favorable attitude towards first aid. It is better to give attention to the training of staff on first aid specifically for teachers working in kindergarten and governmental schools and new employees and consider integrating first aid in teachers' training curriculum. 


\section{List Of Abbreviations}

AOR; Adjusted Odds Ratio, Cl; Confidence Interval, EMS Emergency medical service, EMT; Emergency medical technician, SPSS; Statistical Package for Social Sciences

\section{Declarations}

\section{Ethics approval and consent to participate:}

Before conducting the study, ethical clearance was obtained from the institutional review board of the University of Gondar. A written permission letter was obtained from school directors. Participants were informed about the purpose of the study and written informed consent was obtained from them.

Confidentiality was maintained by omitting direct personal identifiers on the questionnaire, by using code numbers, storing data locked with a password, and not misuse or wrongfully disclose their information. Participants were also informed that participation was voluntary and they can withdraw from the study participation at any stage if they are not comfortable with the investigation. The study protocol is performed in accordance with the relevant guidelines.

\section{Consent for publication:}

Not applicable.

\section{Availability of data and materials:}

The datasets used and/or analyzed during the current study available from the corresponding author on reasonable request.

\section{Funding:}

No funding has been received for the conduct of this study and/or preparation of this manuscript.

\section{Competing interests:}

The authors declared that no conflict of interest exists.

\section{Authors' contributions:}

BSW: participate in the conception and design; analysis and interpretation of data; drafting and revising the manuscript. EGM: took part in the acquisition, analysis, and interpretation of data; drafting the article or revising it critically for important intellectual content; drafting and revising the manuscript. MSA: participate in the analysis and interpretation of data, drafting the manuscript, and revising it. All authors agreed to submit to the current journal; gave final approval of the version to be published; and agree to be accountable for all aspects of the work. 


\section{Acknowledgments:}

The authors are grateful to the University of Gondar, Gondar city administration Education Office, data collectors, and study participants.

\section{References}

1. Zideman DA, De Buck ED, Singletary EM, Cassan P, Chalkias AF, Evans TR, et al. European resuscitation council guidelines for resuscitation 2015 section 9. First aid. Resuscitation. 2015; 95 : 278-87.

2. Markenson D, Ferguson JD, Chameides L, Cassan P, Chung K-L, Epstein JL, et al. Part 13: first aid: 2010 American Heart Association and American Red Cross International Consensus on first aid science with treatment recommendations. Circulation. 2010; 122 (16_suppl_2):S582-S605.

3. Cross IFoR, Societies RC. International first aid and resuscitation, guidelines 2011 for National Society first aid program managers, scientific advisory groups, first aid instructors, and first responders. International Federation of Red Cross and Red Crescent Societies Geneva; 2011.

4. Hussain L, Redmond A. Are pre-hospital deaths from accidental injury preventable? BMJ. 1994; 308 (6936):1077-80.

5. Branche C, Ozanne-Smith J, Oyebite K, Hyder AA. World report on child injury prevention: World Health Organization; 2008.

6. Borse NN, Gilchrist J, Dellinger AM, Rudd RA, Ballesteros MF, Sleet DA. CDC childhood injury report: Patterns of unintentional injuries among 0-19-year-olds in the United States, 2000-2006. 2008.

7. Haagsma JA, Graetz N, Bolliger I, Naghavi M, Higashi H, Mullany EC, et al. The global burden of injury: incidence, mortality, disability-adjusted life years and time trends from the Global Burden of Disease study 2013. Injury prevention. 2016; 22 (1):3-18.

8. Eberl R, Schalamon J, Singer G, Ainoedhofer H, Petnehazy T, Hoellwarth ME. Analysis of 347 kindergarten-related injuries. European journal of pediatrics. 2009; 168 (2):163.

9. Lee ES, Kim C. A study on the occurrences of accidents among children in nursery schools and kindergartens. Journal of Korean Public Health Nursing. 2003; 17 (1):96-112.

10. Alkon A, Genevro JL, Tschann JM, Kaiser P, Ragland DR, Boyce WT. The epidemiology of injuries in 4 child care centers. Archives of pediatrics \& adolescent medicine. 1999; 153 (12):1248-54.

11. Li Q, Alonge O, Lawhorn C, Ambaw Y, Kumar S, Jacobs T, et al. Child injuries in Ethiopia: A review of the current situation with projections. PLoS One. 2018; 13 (3):e0194692.

12. Taklual W, Mekie M, Yenew C. Determinants of First Aid Knowledge and Basic Practice Among Elementary School Teachers in Debre Tabor Town, Northcentral Ethiopia. The Open Public Health Journal. 2020; 13(1).

13. Anmut W, Mesele M, Tekalign T. Knowledge, Attitude and Practice Towards First Aid Among Kindergarten Teachers of Jimma Town, South West, Ethiopia, 2017. Journal of Emergency Medicine 
and Primary Care RD-EMP. 2019; 10008.

14. Ganfure G, Ameya G, Tamirat A, Lencha B, Bikila D. First aid knowledge, attitude, practice, and associated factors among kindergarten teachers of Lideta sub-city Addis Ababa, Ethiopia. PloS one. 2018; 13 (3):e0194263.

15. Yunos R. Knowledge, attitude, and practice of first aid among primary school teachers in petaling Jaya. 2019.

16. Al-Tameemi H, Khudair F. Knowledge and Attitudes of Primary School Teachers toward First Aid in AlNajaf Al-Ashraf City. International Journal of Current Research and Academic Review. 2016; 4 (12):64-79.

17. Mirwanti R, editor ATTITUDE AND KNOWLEDGE OF ELEMENTARY SCHOOL TEACHERS TOWARDS FIRST AID ON EMERGENCY CONDITION IN CHILDREN. International Conference on Disaster Management \& Infection Control; 2017.

18. Alsuhaibani MA, Alharbi S, Alonazy S, Almozeri M, Almutairi M, Alaqeel A. Saudi teachers' confidence and attitude about their role in anaphylaxis management. Journal of family medicine and primary care. 2019; 8 (9):2975.

19. Al Gharsan M, Alarfaj I. Knowledge and practice of secondary school teachers about first aid. Journal of family medicine and primary care. 2019; 8 (5):1587.

20. Israel EU, Ini UM. Evaluation of Teachers Knowledge, Attitude and Practice towards Persons with Epilepsy: There is Need for Educational Interventions. Journal of Advances in Medical and Pharmaceutical Sciences. 2018:1-10.

21. Li F, Jiang F, Jin X, Qiu Y, Shen X. Pediatric first aid knowledge and attitudes among staff in the preschools of Shanghai, China. BMC pediatrics. 2012; 12 (1):121.

22. Midani O, Tillawi T, Saqer A, Hammami MB, Taifour H, Mohammad H. Knowledge and attitude toward first aid: A cross-sectional study in the United Arab Emirates. Avicenna journal of medicine. 2019; 9 (1):1.

23. AlYahya IA, Almohsen HA, AISaleem IA, Al-Hamid MM, Arafah AM, Al Turki YA, et al. Assessment of knowledge, attitude, and practice about first aid among male school teachers and administrators in Riyadh, Saudi Arabia. Journal of family medicine and primary care. 2019; 8 (2):684.

24. Dupoux E, Wolman C, Estrada E. Teachers' attitudes toward integration of students with disabilities in Haiti and the United States. International Journal of Disability, Development, and Education. 2005; $52(1): 43-58$.

25. Galindo Neto NM, Carvalho GCN, Castro RCMB, Caetano JÁ, Santos ECBd, Silva TMd, et al. Teachers' experiences about first aid at school. Revista brasileira de enfermagem. 2018; 71: 1678-84.

\section{Figures}




\section{Knowledge and Attitude towards first aid}

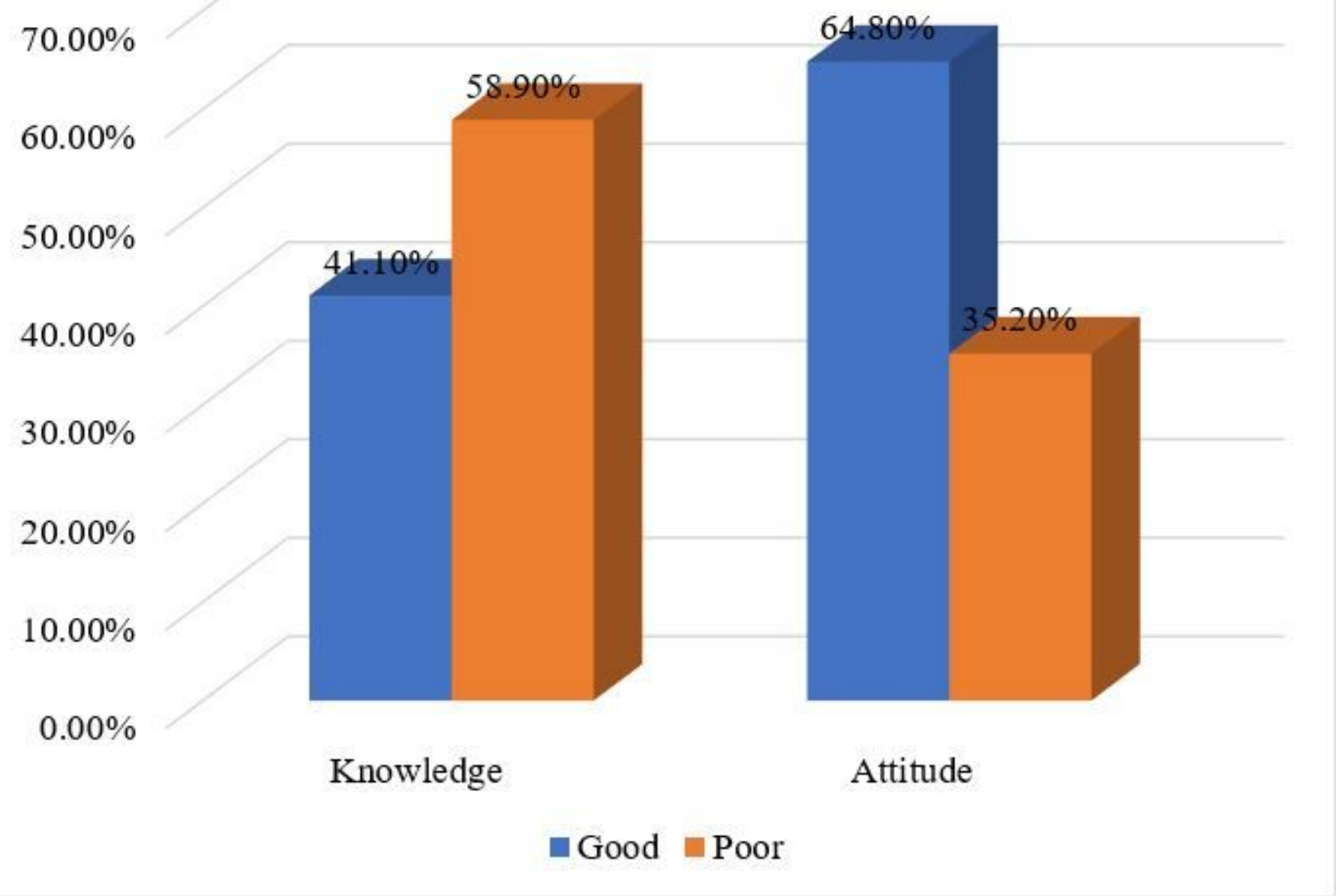

\section{Figure 1}

Knowledge and attitude of kindergarten and elementary schools teachers towards first aid in Gondar city, Northwest Ethiopia, 2021 ( $n=338$ ) 